\title{
Effect of tannic acid on rumen degradation and intestinal digestion of treated soya bean meals in sheep
}

\author{
G. HERVÁS*, P. FRUtos, E. SERRANO, A. R. MANTECÓN And F. J. GiRÁldeZ \\ Estación Agrícola Experimental, CSIC, Apdo 788, 24080-León, Spain \\ (Revised MS received 24 February 2000)
}

\begin{abstract}
SUMMAR Y
The current experiment was conducted to study the effect of different doses of tannic acid, a hydrolysable tannin, on ruminal degradation and post-ruminal digestion of treated soya bean meals (SBM) in sheep. Samples of SBM were prepared by spraying $100 \mathrm{~g} \mathrm{SBM}$ with $100 \mathrm{ml}$ distilled water containing $0,1,5,10,15$ or $25 \mathrm{~g}$ of commercial tannic acid $\left(\mathrm{S}_{0}, \mathrm{~S}_{\mathrm{TA} 1}, \mathrm{~S}_{\mathrm{TA} 2}, \mathrm{~S}_{\mathrm{TA} 3}, \mathrm{~S}_{\mathrm{TA} 4}\right.$ and $\mathrm{S}_{\mathrm{TA} 5}$, respectively). Three ruminally cannulated ewes, that had never consumed tannic acid previously, were used to determine in situ degradability of tannic acid-treated SBM. Intestinal digestibility of protein remaining after $16 \mathrm{~h}$ rumen incubation was estimated in vitro. Extent of rumen degradation of SBMs was significantly $(P<0.05)$ affected by the tannic acid treatment. All doses of tannic acid used in this experiment, even the lowest one $\left(\mathrm{S}_{\mathrm{TA} 1}\right)$, significantly decreased the extent of $\mathrm{N}$ degradation but only doses higher than that used to treat $\mathrm{S}_{\mathrm{TA} 3}$ reduced the extent of $\mathrm{DM}$ degradation. This reduction in the extent of DM and $\mathrm{N}$ degradation was mainly due to a marked decrease in the immediately degradable fraction $(a)$, which was observed in all treated SBM, and to a lower rate of degradation (c), observed in meals $\mathrm{S}_{\mathrm{TA} 3}, \mathrm{~S}_{\mathrm{TA} 4}$ and $\mathrm{S}_{\mathrm{TA} 5}$. Intestinal digestion of the non-degraded protein was decreased $(P<0.05)$ by treatment with the two highest doses of tannic acid (those used to treat meals $\mathrm{S}_{\mathrm{TA} 4}$ and $\mathrm{S}_{\mathrm{TA} 5}$ ). It was therefore concluded that tannic acid can exert a negative effect both on rumen degradation and on intestinal digestion of SBM, this effect being clearly dependent on the dose used to treat the SBM.
\end{abstract}

\section{INTRODUCTION}

Effects of tannins recorded in ruminants include formation of tannin-protein complexes which are stable over a wide range of $\mathrm{pH}$, but dissociate at $\mathrm{pH}$ values of less than 3.5 or more than 8.5 (McLeod 1974). Therefore, in the presence of tannins in the rumen, plant proteins may be bound and protected from microbial degradation, but are released in the abomasum, enabling protein digestion and absorption of amino acids in the small intestine (Barry \& Manley 1984; Barry \& McNabb 1999). On the other hand, anti-nutritional effects of tannins have also been extensively reported (Griffiths 1979; Horigome et al. 1988; Silanikove et al. 1994; Salawu et al. 1999).

However, none of the above observations can be stated as being common for all tannins. Conventional classification of tannins recognizes two major groups: hydrolysable tannins, which consist of a carbohydrate core with phenolic carboxylic acids bound by ester

\footnotetext{
* To whom all correspondence should be addressed. E-mail: hervas@eae.csic.es
}

linkages, and condensed tannins, which consist of oligomers of flavan-3-ols and related flavanol residues which typically produce anthocyanidins on acid degradation (Mueller-Harvey \& McAllan 1992). In addition, each of these two conventional groups consists of a complex array of tannins whose biological activity may differ considerably depending on their chemical structure and molecular weight (Clausen et al. 1990; Hagerman et al. 1992).

Condensed tannins are widely accepted to affect digestibility (Salawu et al. 1997; Barry \& McNabb 1999). Some authors have reported similar effects with tannic acid (Driedger \& Hatfield 1972; Pace et al. 1993) although hydrolysable tannins have often been shown to interact weakly with proteins and even to have no effect on digestibility because they are comprised largely of low molecular weight fractions that may be metabolized (Hagerman et al. 1992; Van Soest 1994).

With the aim of contributing to clarifying this controversy, the present experiment was conducted to study the effect of different doses of tannic acid on ruminal degradation and post-ruminal digestion of treated soya bean meals. 


\section{MATERIAL AND METHODS \\ Animals and diet}

Three individually penned Merino ewes (mean live weight $45 \cdot 7 \mathrm{~kg}$; S.E. $2 \cdot 31$ ), fitted with ruminal cannulae of $35 \mathrm{~mm}$ internal diameter, were used in this experiment. The animals were offered grass hay $(915 \mathrm{~g}$ dry matter $(\mathrm{DM}) / \mathrm{kg} ; 85 \mathrm{~g}$ crude protein $/ \mathrm{kg} \mathrm{DM}$; $610 \mathrm{~g}$ neutral detergent fibre $/ \mathrm{kg} \mathrm{DM}$ ) in two equal meals (at 09.30 and $18.00 \mathrm{~h}$.) at 1.2 times their estimated maintenance requirements for energy (AFRC 1993), for 10 days prior to commencing the experiment and throughout the experimental period. Clean water and vitamin-mineral blocks were always available.

\section{Procedures}

\section{Soya bean meal treatments}

Six samples of $100 \mathrm{~g} \mathrm{SBM} \mathrm{(924} \mathrm{g} \mathrm{DM/kg;} 471 \mathrm{~g}$ crude protein $/ \mathrm{kg} \mathrm{DM} ; 137 \mathrm{~g}$ ash $/ \mathrm{kg} \mathrm{DM}$ ) were ground using a hammer-mill fitted with a $2 \mathrm{~mm}$ screen and sprayed with $100 \mathrm{ml}$ distilled water containing $0,1,5$, 10,15 or $25 \mathrm{~g}$ of tannic acid (TA; Panreac ${ }^{\mathbb{R}}$, Spain). These SBMs, containing $0,1,4 \cdot 8,9 \cdot 1,13 \cdot 0$ and $20 \cdot 0 \mathrm{~g}$ TA/100 g of tannic acid-treated SBM, were labelled $\mathrm{S}_{0}$ (control), $\mathrm{S}_{\mathrm{TA} 1}, \mathrm{~S}_{\mathrm{TA} 2}, \mathrm{~S}_{\mathrm{TA} 3}, \mathrm{~S}_{\mathrm{TA} 4}$ and $\mathrm{S}_{\mathrm{TA} 5}$, respectively. Samples were dried at $40-45{ }^{\circ} \mathrm{C}$ for $24 \mathrm{~h}$ and $2 \mathrm{~mm}$ ground again to remove lumps.

\section{Rumen degradation}

Rumen degradation was measured by in situ methods. Nylon bags $\left(12.0 \times 8.5 \mathrm{~cm}\right.$; Maissa ${ }^{\circledR}$, Spain $)$ made of filter cloth with an approximate pore size of $45 \mu \mathrm{m}$ diameter were used. Four grams (DM) of each SBM were incubated in the rumen of each of the three ewes for $3,6,12,24,48$ and $72 \mathrm{~h}$. Six bags, each containing one of the six treated-meals, were introduced together into the rumen of each sheep before the morning feed. After removal from the rumen (all six at once) the bags were washed with cold water in a commercial washing machine. They were then dried in a forcedair oven at $45^{\circ} \mathrm{C}$ and weighed to determine DM losses. $\mathrm{N}$ concentration in the residues was measured to determine $\mathrm{N}$ losses. Zero-time losses were estimated by washing two bags per sample with the same washing programme used to wash the bags after the incubations.

\section{Intestinal digestion}

Intestinal digestion of protein in the treated SBMs was determined following the three-step in vitro procedure developed by Calsamiglia \& Stern (1995). Each SBM was incubated, using nylon bags, in the rumen of each of the three sheep for $16 \mathrm{~h}$ and the residues thoroughly mixed. Two samples per SBM were used to estimate intestinal digestion of the nondegraded protein. Each residue sample containing $c$. $15 \mathrm{mg} \mathrm{N}$ was incubated for $1 \mathrm{~h}$ in $10 \mathrm{ml}$ of a $0 \cdot 1 \mathrm{M} \mathrm{HCl}$ solution containing $1 \mathrm{~g} / 1$ of pepsin (SIGMA, P-7012). After incubation, $\mathrm{pH}$ was neutralized with $0.5 \mathrm{ml}$ of $1 \mathrm{M} \mathrm{NaOH}$ and $13.5 \mathrm{ml}$ of a $\mathrm{pH} 7 \cdot 80 \cdot 15 \mathrm{~m}$ phosphate buffer containing $3 \mathrm{~g} / 1$ of pancreatin (SIGMA, P7045) were added to the solution and incubated at $38^{\circ} \mathrm{C}$. After a $24-\mathrm{h}$ incubation, $3 \mathrm{ml}$ of a trichloroacetic acid solution ( $1 \mathrm{~g} \mathrm{TCA} / \mathrm{ml}$ distilled water) were added to precipitate undigested proteins. After 15 minutes, samples were centrifuged at $10000 \mathrm{~g}$ for $15 \mathrm{~min}$ and the supernatant analysed for soluble $\mathrm{N}$ by the Kjeldahl method (AOAC 1990).

\section{Chemical analysis}

Procedures described by AOAC (1990) were used to determine DM, ash and Kjeldahl nitrogen (N). NDF was determined by the method of Goering \& Van Soest (1970).

\section{Calculations and statistical analysis}

Dry matter and nitrogen disappearances were fitted to the model described by Ørskov \& McDonald (1979) $\left[d g=a+b\left(1-\mathrm{e}^{(-c t)}\right)\right]$, where $d g$ represents the loss from the bag after $t$ hours, $a$ the fraction that immediately disappears from the bag (intercept), $b$ the fraction that is potentially degraded over time and $c$ the rate of degradation of fraction $b$. The equation was fitted to in situ degradation profiles using the NLIN procedure of the SAS package (SAS 1989).

Extent of degradation (Dg) was estimated by using the parameters $a, b$ and $c$ and a ruminal passage rate $\left(K_{p}\right)$ value of $0 \cdot 08$, according to the equation described by Ørskov \& McDonald (1979): $[\mathrm{Dg}=a+(b c /$ $\left.\left.\left(c+K_{p}\right)\right)\right]$.

Data relating to $\mathrm{DM}$ and $\mathrm{N}$ disappearances were subjected to one-way analysis of variance. The effect of experimental treatments were separately tested for each incubation time with the animal effect as a block. Comparisons among soya bean meals for the rumen degradation parameters and the Dg were also performed using one-way analysis of variance with the animal effect as a block. Comparisons among SBM for intestinal digestion were performed using one-way analysis of variance. The effect of the treatment with tannic acid was partitioned into linear, quadratic and cubic components by using orthogonal polynomials. The LSD test was used to assess the significance of differences between treatment means where the overall treatment effect was significant $(P<0 \cdot 05)$.

All data were analysed using the procedures of the Statistical Analysis Systems (SAS 1989).

\section{RESULTS}

In situ dry matter and nitrogen disappearances of the control and tannic acid treated SBMs are shown in Figs 1 and 2. Tannic acid treatment of SBMs had a negative effect on both DM and $\mathrm{N}$ disappearances 


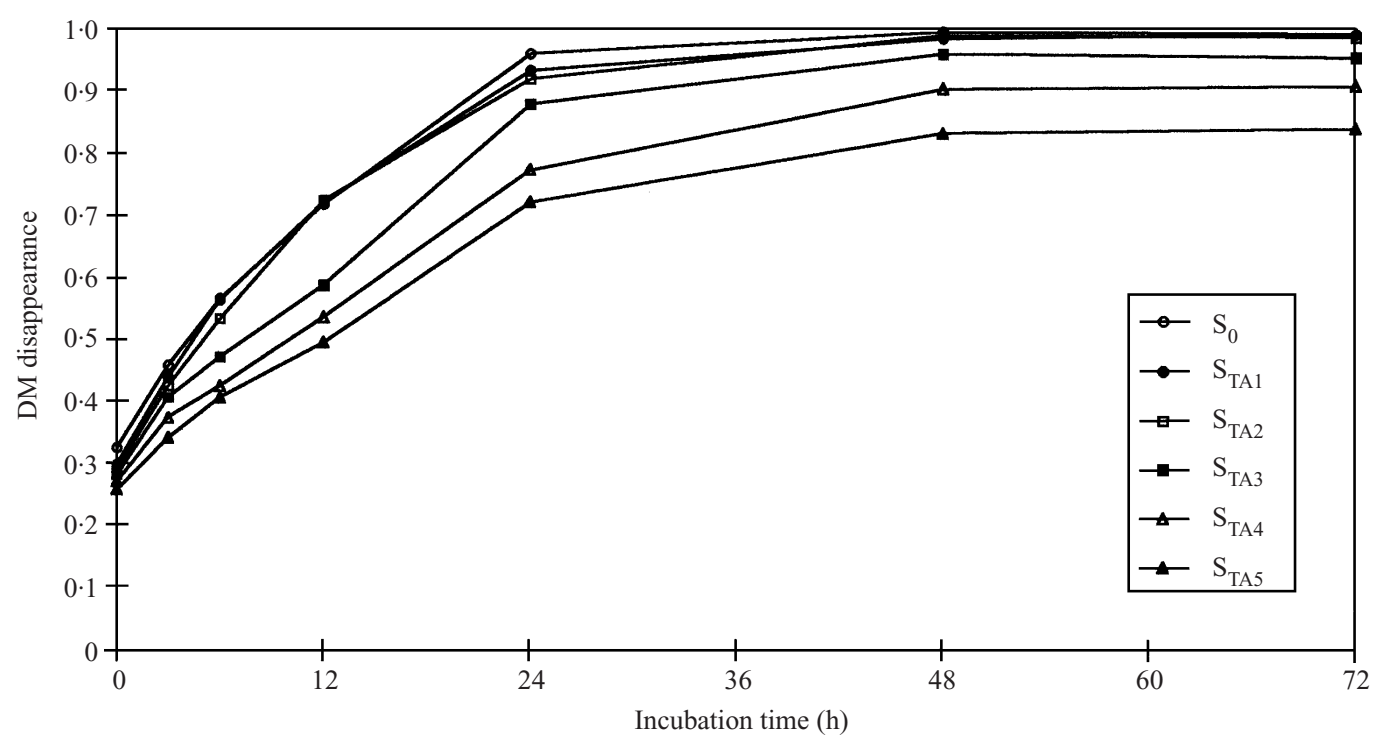

Fig. 1. In situ dry matter disappearances of the control $\left(\mathrm{S}_{0}\right)$ and tannic acid treated soya bean meals ( $\mathrm{S}_{\mathrm{TA} 1}, \mathrm{~S}_{\mathrm{TA} 2}, \mathrm{~S}_{\mathrm{TA} 3}, \mathrm{~S}_{\mathrm{TA} 4}$ and $\left.\mathrm{S}_{\mathrm{TA} 5}\right)$. S.E.s for the tannic acid treatments for each incubation time were 0.0064 (3 h), 0.0102 (6 h), 0.0188 (12 h), 0.0207 $(24 \mathrm{~h}), 0.0108(48 \mathrm{~h})$ and $0 \cdot 0035(72 \mathrm{~h})(\mathrm{D} . \mathrm{F} .=10)$.

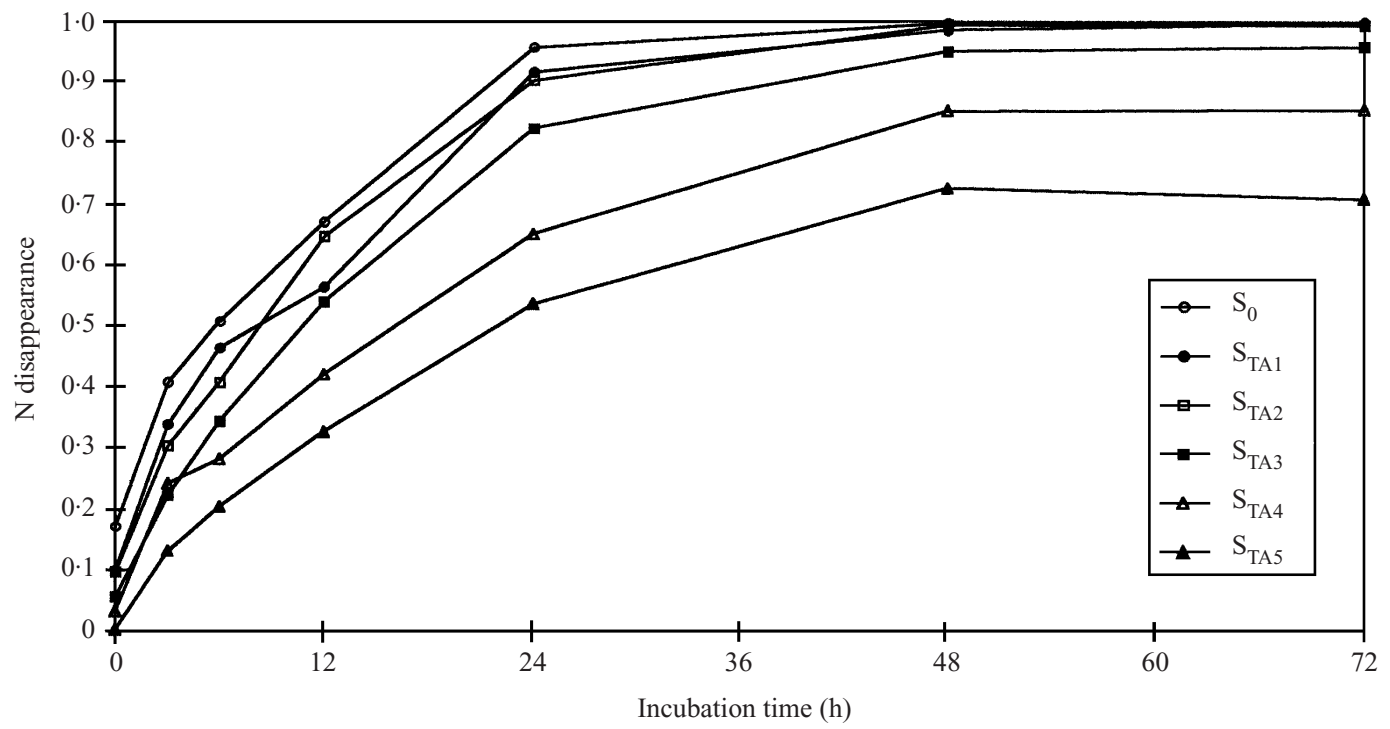

Fig. 2. In situ nitrogen disappearances of the control $\left(\mathrm{S}_{0}\right)$ and tannic acid treated soya bean meals $\left(\mathrm{S}_{\mathrm{TA} 1}, \mathrm{~S}_{\mathrm{TA} 2}, \mathrm{~S}_{\mathrm{TA} 3}, \mathrm{~S}_{\mathrm{TA} 4}\right.$ and $\left.\mathrm{S}_{\mathrm{TA} 5}\right)$. S.E.s for the tannic acid treatments for each incubation time were 0.0171 (3 h), 0.0278 (6 h), $0.0386(12 \mathrm{~h}), 0.0282(24 \mathrm{~h})$, $0 \cdot 0178(48 \mathrm{~h})$ and $0.0078(72 \mathrm{~h})($ D.F. $=10)$.

from bags, this effect being clearly dependent on the incubation time and the dose of tannic acid used to treat the meals.

Ruminal degradation of the different SBMs was reasonably described by the exponential equation defined by Ørskov \& McDonald (1979): $R^{2}=$ $0 \cdot 98 \pm 0.002$ and $\mathrm{RSD}=0.041 \pm 0.0038(n=36)$.
The rumen degradation parameters $(a, b$ and $c$ values) for dry matter and nitrogen of the control and treated SBMs are presented in Table 1. The treatment with tannic acid significantly $(P<0.001)$ decreased the immediately degradable fraction $(a)$. This effect was observed in all the doses studied, and showed a quadratic response $(P<0.001)$. The decrease of the 
Table 1. Dry matter $(D M)$ and nitrogen $(N)$ rumen degradation parameters $(a, b$ and $c$ values), extent of degradation and intestinal digestion of the control $\left(S_{0}\right)$ and tannic acid treated soya bean meals $\left(S_{\text {TA1 }}, S_{T_{A A 2}}, S_{\text {TA3 }}\right.$,

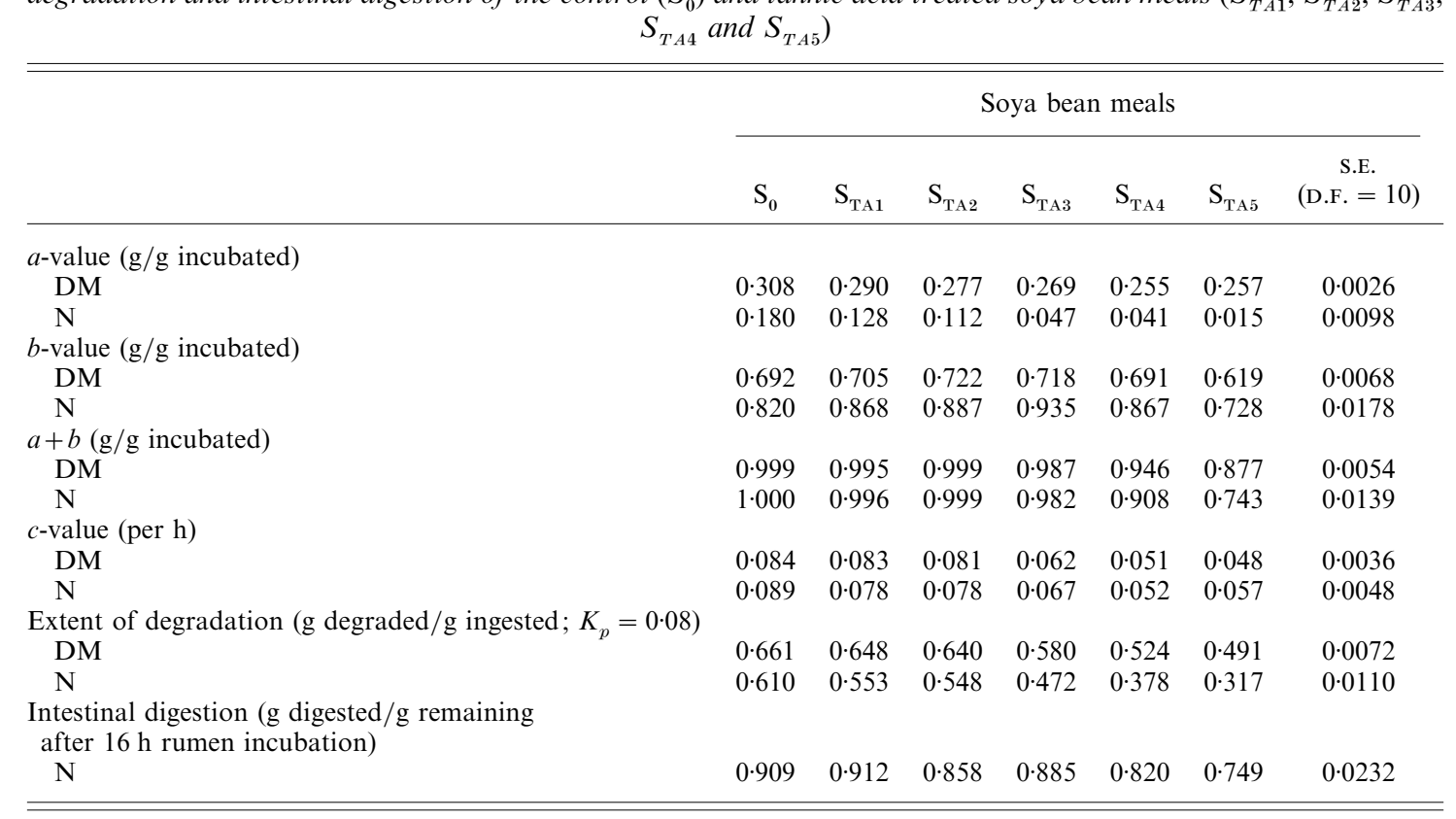

g TA/100 g tannic acid treated-SBM: $\mathrm{S}_{0}=0 ; \mathrm{S}_{\mathrm{TA} 1}=1 ; \mathrm{S}_{\mathrm{TA} 2}=4 \cdot 8 ; \mathrm{S}_{\mathrm{TA} 3}=9 \cdot 1 ; \mathrm{S}_{\mathrm{TA} 4}=13 \cdot 0 ; \mathrm{S}_{\mathrm{TA} 5}=20 \cdot 0$.

immediately degradable $\mathrm{N}$ fraction of the treated SBMs was greater than the reduction observed for the immediately degradable DM fraction.

The quadratic effect of the treatment on the fraction $b$ was also significant $(P<0 \cdot 001)$. Tannic acid treatment increased coefficient $b$ for $\mathrm{N}$ degradation to a maximum value at $\mathrm{S}_{\mathrm{TA} 3}$ but treatments of $\mathrm{S}_{\mathrm{TA} 4}$ and $\mathrm{S}_{\mathrm{TA} 5}$ then reduced $b$. As a whole, the potential degradability values $(a+b)$ were significantly lower (quadratic effect; $P<0.001$ ) in the $\mathrm{S}_{\mathrm{TA} 4}$ and $\mathrm{S}_{\mathrm{TA} 5}$ $(0.946$ and 0.877 for DM and 0.908 and 0.743 for $\mathrm{N}$, respectively) in comparison to the control values (0.999 and 1.000 for DM and N, respectively).

Tannic acid treatment significantly decreased the rate of degradation (linear effect, $P<0.001$ ) but only the three soya bean meals treated with the highest doses of tannic acid $\left(\mathrm{S}_{\mathrm{TA} 3}, \mathrm{~S}_{\mathrm{TA} 4}\right.$ and $\left.\mathrm{S}_{\mathrm{TA} 5}\right)$ showed significant lower rates of degradation $(c)$ than the control meal $\left(\mathrm{S}_{0}\right)$, both for $\mathrm{DM}$ and $\mathrm{N}$.

In line with these degradation parameters, extent of degradation of the soya bean meals (see Table 1) was also significantly affected by the tannic acid treatment (linear effect; $P<0.001$ ). Notwithstanding, while all doses of tannic acid used in this experiment decreased the extent of $\mathrm{N}$ degradation, only meals $\mathrm{S}_{\mathrm{TA} 3}, \mathrm{~S}_{\mathrm{TA} 4}$ and $\mathrm{S}_{\mathrm{TA} 5}$ showed significantly lower values of the extent of DM degradation than the control.

Intestinal digestion of the non-degraded protein was decreased by the treatment with tannic acid (linear effect; $P<0 \cdot 01$ ), the values being 0.909, 0.912, $0 \cdot 858,0 \cdot 885,0 \cdot 820$ and 0.749 for $\mathrm{S}_{0}, \mathrm{~S}_{\mathrm{TA} 1}, \mathrm{~S}_{\mathrm{TA} 2}, \mathrm{~S}_{\mathrm{TA} 3}$, $\mathrm{S}_{\mathrm{TA} 4}$ and $\mathrm{S}_{\mathrm{TA} 5}$ (S.E. $=0.0232$; D.F. $=6$ ). The reduction was only statistically significant in meals $\mathrm{S}_{\mathrm{TA} 4}$ and $\mathrm{S}_{\mathrm{TA} 5}$.

\section{DISCUSSION}

In a recent review by Foley et al. (1999), a lack of an effect of hydrolysable tannins on digestibility is not considered surprising, given the ease with which they can be metabolized.

There is sufficient evidence in the literature to suggest degradation of hydrolysable tannins by rumen microbes. Strains of rumen bacterial species that cleave structural bonds in the hydrolysable tannins enzymatically and utilize the degradation products have been described in several studies (Nelson et al. 1995; Skene \& Brooker 1995). However, this does not necessarily mean that hydrolysable tannins are unable to protect protein against ruminal degradation.

According to the results found in the current experiment, tannic acid was able to significantly reduce ruminal degradation of the SBM. Similar observations were obtained by Driedger \& Hatfield (1972), Pace et al. (1993) and Makkar et al. (1995), when studying different doses of tannic acid.

As expected, the effect of the treatment with tannic acid was always more marked for $\mathrm{N}$ than for $\mathrm{DM}$, given the strong hydrogen bond affinity of the phenolic 
groups of the tannin molecule with the carbonyl oxygen of the peptide group (McLeod 1974). Thus, all doses studied, even the lowest one $\left(\mathrm{S}_{\mathrm{TA} 1}\right)$, were able to decrease the extent of $\mathrm{N}$ degradation but only doses higher than $9 \mathrm{~g}$ TA/100 $\mathrm{g}$ of tannic acid-treated SBM $\left(\mathrm{S}_{\mathrm{TA} 3}\right)$ reduced significantly the extent of DM degradation.

The reduction of the extent of degradation of the SBM by the treatment with tannic acid was basically due to a marked reduction of the immediately degradable fraction $(a)$, which was observed in all treated SBM, and to a lower rate of degradation (c), observed in meals $\mathrm{S}_{\mathrm{TA} 3}, \mathrm{~S}_{\mathrm{TA} 4}$ and $\mathrm{S}_{\mathrm{TA} 5}$. This last point, a lower value of $c$, is consistent with the results reported by most authors. Nevertheless, results from in vitro gas production studies (Makkar et al. 1995) indicate that tannic acid does not reduce the potential extent of digestion $(a+b ; \mathrm{ml})$. It must be considered, however, that the highest dose used in that study was similar to the dose used in the current experiment to treat the meal $\mathrm{S}_{\mathrm{TA} 3}$ and that the significant reduction in the potential degradability $(a+b)$ was only observed with the two highest doses (those used to treat $\mathrm{S}_{\mathrm{TA} 4}$ and $\mathrm{S}_{\mathrm{TA} 5}$ ), both for the DM and the $\mathrm{N}$.

Intestinal digestion of the non-degraded protein of the treated SBM was not detrimentally affected by the tannic acid treatment up to the dose used to treat the $\mathrm{S}_{\mathrm{TA} 3}$, i.e. up to $10 \mathrm{~g}$ per $100 \mathrm{~g}$ of SBM $(9 \mathrm{~g} \mathrm{TA} / 100 \mathrm{~g}$ of tannic acid-treated SBM). These results are comparable to the results found previously when commercial quebracho was examined as an additive to improve the digestive utilization of SBM in sheep (Frutos et al. 2000).

The lower intestinal digestion observed in meals $\mathrm{S}_{\mathrm{TA} 4}$ and $\mathrm{S}_{\mathrm{TA} 5}$ contrasts with the general hypothesis that hydrolysable complexes were digestible whereas components bound by condensed tannins were probably resistant to attack by proteases (Silanikove et al. 1994; Van Soest 1994). Nevertheless, both increased and reduced activities of intestinal enzymes due to the effect of different doses of tannins have been found in vitro (Mole \& Waterman 1985).

In the present experiment, it appears evident that the overall effect of the tannic acid on the digestive utilization of the treated SBM in sheep is clearly dependent on the dose.

Using data available in the literature (Driedger \& Hatfield 1972; Pace et al. 1993; Makkar et al. 1995; Frutos et al. 2000), it seems clear that the effect of the tannic acid is less marked compared to the effect of condensed tannins. This could be due to the ease with which these polyphenols can be metabolized by rumen micro-organisms. Nevertheless, in the present experiment, the action of the microbes was not enough to overcome the effect of the tannic acid. It is noteworthy that the animals used in this trial had never consumed tannic acid previously. Therefore, their rumen microbial population was not adapted to degrade this product. In several circumstances, it has been shown that a gradual increase in the intake of a secondary compound by the ruminant increases the ability of its ruminal micro-organisms to metabolize that compound (Quirk et al. 1988; Skene \& Brooker 1995; Duncan et al. 1997).

Presumably then, the current controversy about the existence or not of an effect of the hydrolysable tannins on digestibility could be also explained, in addition to the dose, by the adaptation or not of the rumen population of the animals used in each experiment to degrade these tannins.

Although the results relative to the digestive utilization of tannic acid-treated SBM found in the current experiment are close to the results reported previously when using commercial quebracho (Frutos et al. 2000), the potential use of tannic acid as a chemical additive is still far from clear. First, because given the hydrolysable nature of these tannins, they could be degraded in the rumen and then absorbed causing toxicity to the animal. Second, because the possibility of its degradation by adapted ruminal micro-organisms could reduce or even invalidate the effectiveness of the tannic acid treatment in improving digestive utilization of SBM.

In conclusion, the current results show that tannic acid can exert a negative effect both on rumen degradation and on intestinal digestion of the SBM, this effect being clearly dependent on the dose used to treat the SBM. It is considered that this effect is also probably dependent on the adaptation of the rumen microbial population to the presence of tannic acid, which would increase its ability to degrade this compound. Obviously, this is not a conclusion but a working hypothesis for further research with the aim of understanding the behaviour of the tannic acid.

The authors wish to thank Dr S. López for helpful comments and revision of the manuscript. This work was supported by the Inter-ministerial Commission of Science and Technology (CICYT) of Spain (Project AGF98-0874) and the Junta de Castilla y León (Project CSI 7/98).

\section{REFERENCES}

AFRC (1993). Energy and Protein Requirements of Ruminants. An advisory manual prepared by the AFRC Technical Committee on responses to nutrients. Wallingford, UK: CAB International.

AOAC (1990). Official Methods of Analysis of the Association of Official Agricultural Chemists. 15th edn. Washington, DC: AOAC

BARRY, T. N. \& MANLey, T. R. (1984). The role of condensed tannins in the nutritional value of Lotus pedunculatus for sheep. British Journal of Nutrition 51, 493-504. 
Barry, T. N. \& McNabB, W. C. (1999). The implications of condensed tannins on the nutritive value of temperate forages fed to ruminants. British Journal of Nutrition 81, 263-272.

Calsamiglia, S. \& Stern, M. D. (1995). A three-step in vitro procedure for estimating intestinal digestion of protein in ruminants. Journal of Animal Science 73, 1459-1465.

Clausen, T. P., Provenza, F. D., Burritt, E. A., Reichardt, P. B. \& Bryant, J. P. (1990). Ecological implications of condensed tannin structure: a case study. Journal of Chemical Ecology 16, 2381-2392.

Driedger, A. \& Hatfield, E. E. (1972). Influence of tannins on the nutritive value of soybean meal for ruminants. Journal of Animal Science 34, 465-468.

Duncan, A. J., Frutos, P. \& Young, S. A. (1997). Rates of oxalic acid degradation in the rumen of sheep and goats in response to different levels of oxalic acid administration. Animal Science 65, 451-455.

Foley, W. J., Iason, G. R. \& McArthur, C. (1999). Role of secondary metabolites in the nutritional ecology of mammalian herbivores: how far have we come in 25 years? In Nutritional Ecology of Herbivores (Eds H-J. G. Jung \& G. C. Fahey, Jr.), pp. 130-209. Illinois, USA: American Society of Animal Science.

Frutos, P., Hervás, G., Giráldez, F. J., Fernández, M. \& Mantecón, A. R. (2000). Digestive utilisation of quebracho-treated soya bean meals in sheep. Journal of Agricultural Science, Cambridge 134, 101-108.

Goering, M. K. \& Van Soest, P. J (1970). Forage fiber analysis (apparatus, reagents, procedures and some applications). Agriculture Handbook, No 379. Washington, USA: Agricultural Research Service, USDA.

GrIFFITHS, D. W. (1979). The inhibition of digestive enzymes by extracts of field bean (Vicia faba). Journal of the Science of Food and Agriculture 30, 458-462.

Hagerman, A. E., Robbins, C. T., Weerasuriya, Y., Wilson, T. C. \& McArthur, C. (1992). Tannin chemistry in relation to digestion. Journal of Range Management $\mathbf{4 5}$, $57-62$.

Horigome, T., Kumar, R. \& OKamoto, K. (1988). Effects of condensed tannins prepared from leaves of fodder plants on digestive enzymes in vitro and in the intestine of rats. British Journal of Nutrition 60, 275-285.

MakKaR, H. P. S., BlüMmel, M. \& BeCKer, K. (1995). In vitro effects of and interactions between tannins and saponins and fate of tannins in the rumen. Journal of the Science of Food and Agriculture 69, 481-493.
McLeod, M. N. (1974). Plant tannins - Their role in forage quality. Nutrition Abstracts and Reviews 44, 803-812.

Mole, S. \& Waterman, P. G. (1985). Stimulatory effects of tannins and cholic acid on tryptic hydrolysis of proteins: ecological implications. Journal of Chemical Ecology 11, 1323-1332.

Mueller-Harvey, I. \& McAllan, A. B. (1992). Tannins. Their biochemistry and nutritional properties. Advances in Plant Cell Biochemistry and Biotechnology 1, 151-217.

Nelson, K. E., Pell, A. N., Schofield, P. \& Zinder, S. (1995). Isolation and characterization of an anaerobic ruminal bacterium capable of degrading hydrolyzable tannins. Applied and Environmental Microbiology 61, 3293-3298.

ØRSKOV, E. R. \& McDonald, I. (1979). The estimation of protein degradability in the rumen from incubation measurements weighed according to the rate of passage. Journal of Agricultural Science, Cambridge 92, 499-503.

Pace, V., Settineri, D. \& Catillo, G. (1993). Influenza di trattamenti con tannini sulla digeribilità in vitro della farina di soia. Zootecnia i Nutricion Animali 19, 73-79.

Quirk, M. F., Bushell, J. J., Jones, R. J., Megarrity, R. G. \& Butler, K. L. (1988). Live-weight gains on leucaena and native grass pastures after dosing cattle with rumen bacteria capable of degrading DHP, a ruminal metabolite from leucaena. Journal of Agricultural Science, Cambridge 111, 165-170.

Salawu, M. B., Acamovic, T., Stewart, C. S. \& Hovell, F. D. DeB. (1997). Quebracho tannins with or without Browse Plus (a commercial preparation of polyethylene glycol) in sheep diets: effect on digestibility of nutrients in vivo and degradation of grass hay in sacco and in vitro. Animal Feed Science and Technology 69, 67-78.

Salawu, M. B., Acamovic, T., Stewart, C. S. \& Hovell, F. D. DeB. (1999). Effects of feeding quebracho tannin diets, with or without a dietary modifier, on rumen function in sheep. Animal Science 69, 265-274.

SAS (1989). SAS/STAT ${ }^{\circledR}$ User's Guide Int (Version 6, $4^{\text {th }}$ Edn) Statistical Analysis Systems Institute Inc., Cary, NC. Silanikove, N., Nitsan, Z. \& Perevolotsky, A. (1994). Effect of a daily supplementation of polyethylene glycol on intake and digestion of tannin-containing leaves (Ceratonia siliqua) by sheep. Journal of Agriculture and Food Chemistry 42, 2844-2847.

Skene, I. K. \& BRoOKer, J. D. (1995). Characterization of tannin acylhydrolase activity in the ruminal bacterium Selenomonas ruminantium. Anaerobe 1, 321-327.

Van Soest, P. J. (Ed.). (1994). Nutritional Ecology of the Ruminant. 2nd edn. Ithaca: Cornell University Press. 